IJJM

Ilomata International Journal of Management

P-ISSN: 2714-8971; E-ISSN: 2714-8963

Vol. 1 No. 4 October 2020 pp.215-227

https://www.ilomata.org/index.php/ijim

\title{
Effect of Emotional Experience, Electronic Word of Mouth, Reputation, Customer Satisfaction on Loyalty (Empirical Study: Lion Air)
}

\author{
Brendi Wijaya $^{1}$, Henilia Yulita ${ }^{2}$ \\ ${ }^{12}$ Bunda Mulia University \\ correspondent: bwijaya@bundamulia.ac.id
}

Submitted : October 21, 2020 Revised : October 25, 2020 Published : October 30, 2020

\begin{abstract}
Lion Air was chosen by the public as an airline because of its lower fares compared to other airlines. However, Lion Air also often creates problems in terms of service, namely passenger displacement due to delay. With a negative emotional experience will have an effect on reputation decline, due to electronic word of mouth by consumers who are dissatisfied with the service. This type of research uses quantitative methods. The population of this research is all consumers who have used Lion Air transportation services with a sample of 100 respondents. The data collection method uses purposive sampling method. Technical analysis using SMART PLS 3.0 consists of three types, namely instrument testing, prerequisite tests, and hypothesis testing. The results showed that consumer satisfaction is influenced by emotional experience, E-Wom is influenced by emotional experience, reputation is not influenced by emotional experience, loyalty is not influenced by customer satisfaction, E-Wom is influenced by customer satisfaction, reputation is influenced by consumer satisfaction, Loyalty is influenced by Reputation, Reputation is influenced by E-Wom, and Loyalty is also influenced by E-Wom.
\end{abstract}

Keywords: Emotional Experience, E-Wom, Customer Satisfaction, Reputation, Loyalty

\section{INTRODUCTION}

Indonesia is an archipelago consisting of 17,504 islands with a population of nearly $270,054,853$ million people in 2018. As an archipelagic country, Indonesia needs transportation that can connect all regions easily. Transportation itself is a link of various regions in Indonesia where transportation has now become a basic need of the community to fulfill their daily activities, both land, sea and air transportation.

Based on data from the Ministry of Transportation in the last four years, in Indonesia there are 10 new airports built from Kertajati Airport in Majalengka to Berau Airport in East Kalimantan. This is the impact of increased use of air transportation (Hartomo, 2018). The Central Statistics Agency noted the number of airplane passengers for domestic flights in October 2018 increased $6.85 \%$ to 8.11 million people and also grew 7.85\% compared to October the previous year. Similarly, the cumulative period for January-October this year grew $6.98 \%$ to 78.63 million people compared to the same period in 2017. (databoks.katadata.co.id, 2018).

So far, Lion Air has been chosen by the public as an airline because of its lower fares compared to other airlines. However, Lion Air also often creates problems in terms of service, namely passenger displacement due to delay. The latest incident was (Sukmana, 2018). The last event occurred was the Lion Air plane crash with flight number JT-780 from Makassar to Palu City, around 22:20 West Indonesia Time, Tuesday (02/12/2019), experiencing turbulence in the Makassar Strait waters. The plane, which actually flew from Surabaya, East Java, to Palu, Central 
Effect of Emotional Experience, Electronic Word of Mouth, Reputation, Customer Satisfaction on Loyalty (Empirical Study: Lion Air)

Wijaya \& Yulita

Sulawesi, was transiting at Sultan Hasanuddin Makassar International Airport in Maros Regency. (makassar.tribunnews.com, 2019).

Indirectly with the existence of various incidents will form an emotional experience experienced by consumers and can have an impact on customer satisfaction. With the existence of consumer satisfaction will certainly encourage consumers to do electronic word of mouth. Negative emotional experience will create dissatisfaction with a consumer, and from that dissatisfaction encourages consumers to do negative electronic word of mouth as well as influencing others not to use Lion Air airline services, coupled with the presence of social media which has a greater impact because wide reach. With a negative emotional experience will have an effect on reputation decline, due to electronic word of mouth by consumers who are dissatisfied with the service. Therefore, emotional experience, customer satisfaction, electronic word of mouth and reputation will influence consumer loyalty to a product.

There are several studies which state that electronic word of mouth (E-WOM) has a direct effect on loyalty. Positive e-WOM can also persuade potential customers and influence consumer perceptions of product reviews or products recommended by other customers. E-WOM also has an influence on consumer loyalty where the more frequent and more positive E-WOM consumers do on social media, shows the greater level of consumer loyalty (Serra-Cantallops, RamonCardona, \& Salvi, 2018).

However, research (Setiawan, Troena, Armanu, \& Noermijati, 2014) states that electronic word of mouth has no effect on loyalty. This contradicts the results of research which states that electronic word of mouth influences loyalty (Serra-Cantallops, Ramon-Cardona, \& Salvi, 2018). Based on the background that has been described previously, researchers identified the purpose of this study were (1) knowing the effect of emotional experience on customer satisfaction, electronic word of mouth, the reputation of the airline Lion Air and (2) knowing the effect of electronic word of mouth, customer satisfaction and reputation for Lion Air airline consumer loyalty.

According to (Mirza, 2016), emotional experience can make a consumer continue to use a product because of feelings that make consumers trust and cause a bond between consumers and the product, thus creating a commitment. Consumer experience of a product can affect a long-term memory which from experience becomes an attachment and like a product then leads to loyalty. Increasing the emotional strength positively towards service providers, the loyalty will also increase. (Suhasto, 2018).

Electronic word of mouth is defined as all informal communication directed at consumers via internet technology related to the use or characteristics of certain goods and services, or the seller (Serra-Cantallops, 2018). Traditional word of mouth has evolved into electronic word of mouth in the digital era now. The main difference between WOM and e-WOM can be seen from the range of impact of the review (number of people who can be influenced) and the speed of interaction. Therefore, when compared to traditional word of mouth, electronic word of mouth is more influential because of its speed, convenience, reach of one-to-many (one consumer to many consumers or the community, the environment), and the absence of face-to-face between consumers.

Reputation is an important role in consumer perceptions of companies, companies that have a good reputation tend to be considered more trustworthy consumers when compared to companies that have a bad reputation because consumers consider reputation can reduce the 
Effect of Emotional Experience, Electronic Word of Mouth, Reputation, Customer Satisfaction on Loyalty (Empirical Study: Lion Air)

Wijaya \& Yulita

perceived risk when consuming. A good company reputation also tends to attract more consumers and can retain its customers (Widanaputra, 2018).

States that customer satisfaction results in an increase in the attitude of repeat purchases. Satisfaction as an emotional reaction to consumers obtained from certain transactions. Therefore, customer satisfaction is important in attracting and influencing consumers' emotions and making consumers loyal to the company (Lestari, 2018).

The level of customer loyalty is considered high when consumers have a strong and favorable perception of the company's reputation. In the service industry also called service loyalty means loyal customers to certain brands in the service industry. Therefore, consumers will maintain loyalty in a company if consumers are satisfied. (Sustainable, 2018).

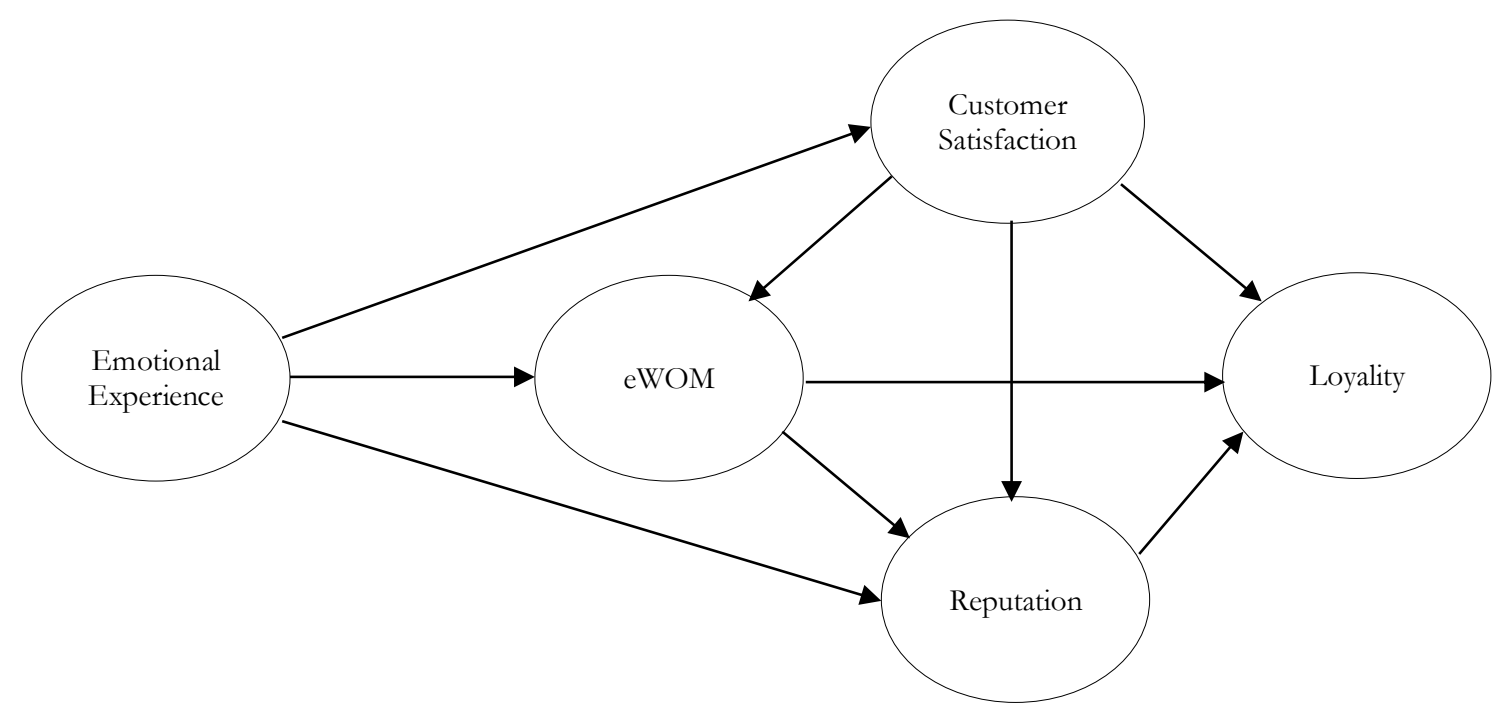

Picture 1.

Conceptual Framework

Source: Researcher (2020)

The hypothesis is a temporary answer to the formulation of the problem in research. The following hypotheses contained in this study:

1. Positive emotional experience has a positive effect on customer satisfaction.

2. Positive emotional experience has a positive effect on electronic word of mouth.

3. Positive emotional experiences have a positive effect on reputation.

4. Consumer satisfaction has a positive effect on loyalty.

5. Consumer satisfaction has a positive effect on electronic word of mouth.

6. Consumer satisfaction has a positive effect on reputation.

7. Reputation has a positive effect on loyalty.

8. Electronic word of mouth has a positive effect on reputation.

9. Electronic word of mouth has a positive effect on loyalty

\section{METHODS}

The research method is a data collection technique that needs to be formulated appropriately. The object of research is a problem, issue or problem that is discussed, researched and investigated in social research. Objects are problems that are studied in research, then with a brief understanding. While the research subjects were informants or informants from which the research data came from. (Bara, 2020). The object of this research is emotional experience, electronic word 
Effect of Emotional Experience, Electronic Word of Mouth, Reputation, Customer Satisfaction on Loyalty (Empirical Study: Lion Air)

Wijaya \& Yulita

of mouth (eWOM), customer satisfaction, reputation, and loyalty. and in this study the research subjects were passengers of the Lion Air airline.

This research uses explanatory research (explanatory research) with a quantitative approach. In explanatory research, the explanation of the relationship (causality) between variables through hypothesis testing (Solimun, Armanu, \& Fernandes, 2018, pp. 6-7). This type of research was chosen based on the attractiveness of the problem and the curiosity of researchers on the phenomenon of the Lion Air airline incident on the JT-780 flight from Makassar to Palu City, Tuesday (12/2/2019) which experienced turbulence in the waters of the Makassar Strait.

This study uses data collection techniques with survey methods. This method is done by giving or distributing questionnaires to respondents. Respondents will be asked to fill in their own questionnaire in accordance with their assessment and perception. This method is effective, if the researcher believes that the respondent has understood the questions well in the questionnaire (Solimun, Armanu, \& Fernandes, 2018, p. 86). In this study, data collection is done by distributing questionnaires online to consumers.

According to (Solimun, Armanu, \& Fernandes, 2018, p. 133), the population can be defined as the entire sample unit within the area of the generalization of research results. In this study, the population is unknown, where respondents are consumers who have used the Lion Air airline and have read articles or news about Lion Air airlines. This population selection is based on emotional experience variables where respondents are those who have used Lion Air as a means of air transportation. In addition to using Lion Air, respondents are also those who have read or heard news about Lion Air flight accidents on JT-780 flights from Makassar to Palu City, Tuesday $(12 / 2 / 2019)$ who experienced turbulence in the Makassar Strait waters, so that respondents can answer clearly about the reputation of the Lion Air airline.

A small portion representing a population is called a sample. The sample is part of a unit that is representative of the population (Solimun, Armanu, \& Fernandes, 2018, p. 136). The nonprobability sampling technique used was purposive sampling, wherein the sample was chosen with consideration in accordance with the research objectives (Solimun, Armanu, \& Fernandes, 2018, pp. 156-158). The number of samples in this study were 20 indicators x $5=100$ respondents.

The measurement results of the validity test are units that prove accurately with the facts or actual conditions of the thing being measured (Matondang, 2009). A study is said to have high validity if the measuring device gives the same results or in accordance with the measurement objectives (Isdianto \& Kurniawan, 2017).

Reliability in a study refers to the standardization of measuring instruments used in the study (Afiyanti, 2008). The reliability test is closely related to the inconsistency of the results of measurements when re-measuring the same group of subjects (Matondang, 2009).

The coefficient of determination is a measuring tool to determine the ability of the model in explaining variations in the dependent variable (Isdianto \& Kurniawan, 2017). The coefficient of determination is a common unit for measuring the feasibility of a model (Noviyanti, Yuniarti, \& Amijaya, 2016).

The significance test ( $t$ test) is a measurement tool to determine the effect of each independent variable individually (partial) on the dependent variable (Isdianto \& Kurniawan, 2017). 
Effect of Emotional Experience, Electronic Word of Mouth, Reputation, Customer Satisfaction on Loyalty (Empirical Study: Lion Air)

Wijaya \& Yulita

\section{RESULTS AND DISCUSSION}

In this study, the number of respondents obtained through the distribution of questionnaires online was 109 respondents. Of the 109 respondents collected, there were only 100 respondents who met the research criteria. The results of 100 respondents showed that most respondents were female, amounting to 54 respondents. A total of 51 respondents aged between 17 - 65 years. Most respondents 'occupations were employees with a total of 45 respondents, while most respondents' expenditures were Rp. 2,500,001 - up to Rp. 5,000,000 - totaling 50 respondents.

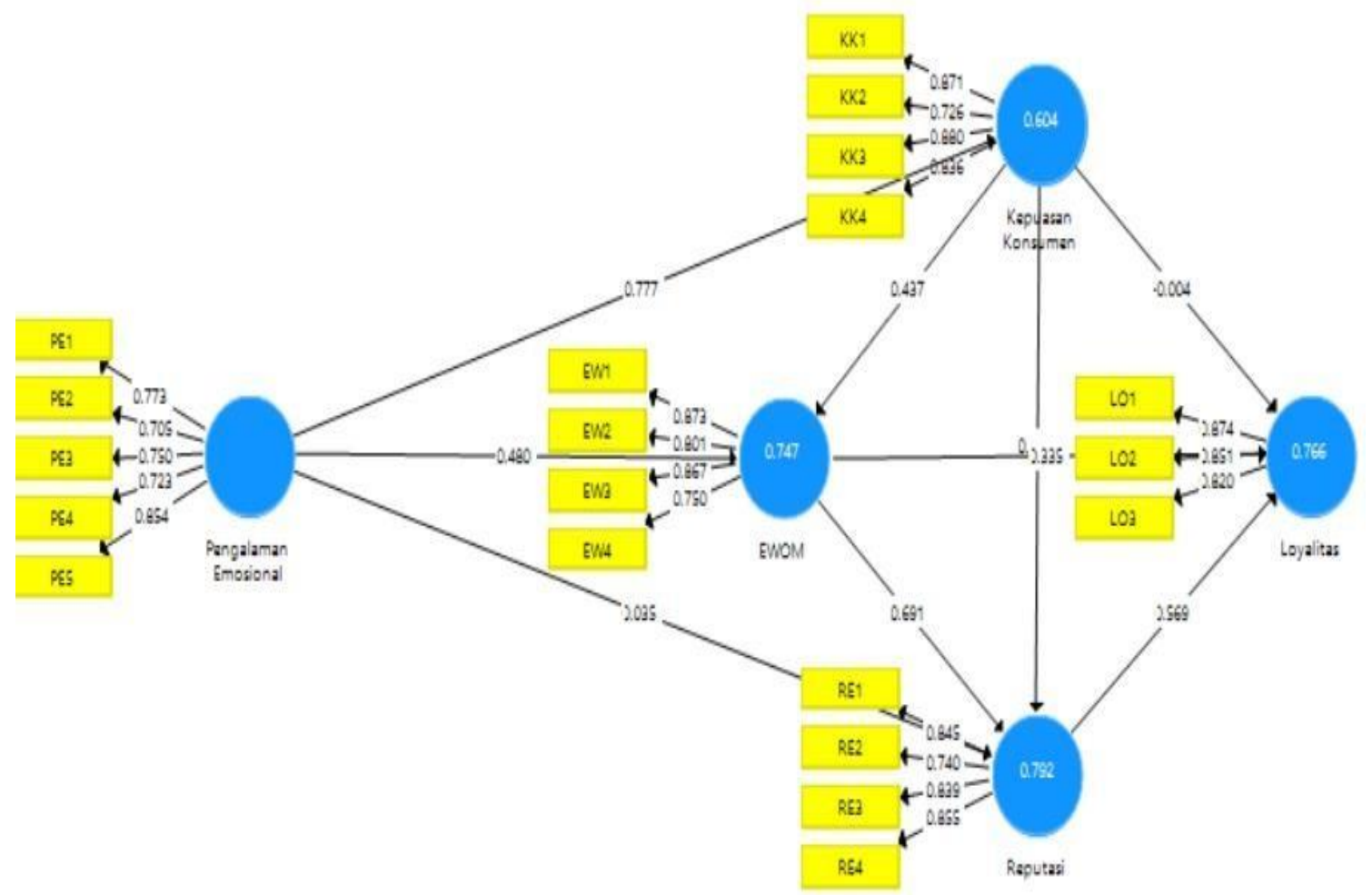

Picture 2.

SmartPLS 03 calculation

Source: SmartPLS 03 calculation results, $\mathrm{n}=100$

(2020)

Based on the data show calculations using SmartPLS 3.0 and perform PLS Algorithm calculations with all the existing indicators of each variable. Tests in PLS Algorithm show the results to test the validity, reliability and determination tests which consist of cross loadings, outer loadings, AVE (Average Variance Extracted, Cronbach's alpha, composite reliability and R-square. statistics in deducing the results of the relationship between variables.

Validity test can be done by testing discriminant validity and convergent validity.

Table 1.

Cross Loadings

\begin{tabular}{c|l|c|c|c|c}
\hline & EWO & Consumer & Loyalty & Emotional & Reputatio \\
\hline EW1 & 0.873 & 0.722 & 0.758 & 0.754 & 0.773 \\
\hline EW2 & 0.801 & 0.629 & 0.614 & 0.680 & 0.689 \\
\hline EW3 & 0.867 & 0.656 & 0.755 & 0.651 & 0.757 \\
\hline EW4 & 0.750 & 0.662 & 0.606 & 0.612 & 0.681
\end{tabular}


Effect of Emotional Experience, Electronic Word of Mouth, Reputation, Customer Satisfaction on Loyalty (Empirical Study: Lion Air)

Wijaya \& Yulita

\begin{tabular}{c|l|c|c|c|c}
\hline & EWO & Consumer & Loyalty & Emotional & Reputatio \\
\hline KK1 & 0.777 & 0.871 & 0.714 & 0.751 & 0.754 \\
\hline KK2 & 0.492 & 0.726 & 0.401 & 0.470 & 0.479 \\
\hline KK3 & 0.712 & 0.880 & 0.643 & 0.689 & 0.732 \\
\hline KK4 & 0.663 & 0.836 & 0.560 & 0.625 & 0.597 \\
\hline LO1 & 0.788 & 0.617 & 0.874 & 0.641 & 0.782 \\
\hline LO2 & 0.693 & 0.634 & 0.851 & 0.609 & 0.738 \\
\hline LO3 & 0.628 & 0.567 & 0.820 & 0.562 & 0.664 \\
\hline PE1 & 0.636 & 0.596 & 0.532 & 0.773 & 0.585 \\
\hline PE2 & 0.519 & 0.458 & 0.476 & 0.705 & 0.484 \\
\hline PE3 & 0.634 & 0.581 & 0.499 & 0.750 & 0.548 \\
\hline PE4 & 0.645 & 0.629 & 0.623 & 0.723 & 0.620 \\
\hline PE5 & 0.674 & 0.672 & 0.576 & 0.854 & 0.630 \\
\hline RE1 & 0.769 & 0.683 & 0.763 & 0.703 & 0.845 \\
\hline RE2 & 0.661 & 0.582 & 0.609 & 0.518 & 0.740 \\
\hline RE3 & 0.739 & 0.678 & 0.738 & 0.661 & 0.839 \\
\hline RE4 & 0.719 & 0.634 & 0.707 & 0.588 & 0.855 \\
\hline
\end{tabular}

Source: SmartPLS 03 calculation results, $\mathrm{n}=100$

(2020)

In this study, all variables are anonymized so that the emotional experience variable becomes PE1- PE5, the electronic word of mouth variable becomes EW1-EW4, the consumer satisfaction variable becomes KK1-KK4, the reputation variable becomes RE1-RE4 and the loyalty variable becomes LO1-LO3 while the numbers represent number of question indicators in the variable.

The value of cross loadings in table 1 can be concluded that the value of each indicator forming the parent variable when associated with different variables does not correlate with height compared to the correlation with the parent variable. The indicator is said to be not highly correlated because the value of the indicator when connected with other variables results in a value smaller than 0.7. The value of each indicator forming the parent variable is highly correlated because it produces a value greater than 0.7 thus it can be concluded that each indicator of the forming of the parent variable has fulfilled the discriminant validity test requirements.

Table 2.

AVE

\begin{tabular}{cc}
\hline & AVE \\
\hline E-Wom & 0.679 \\
\hline Consumer Satisfaction & 0.690 \\
\hline Loyalty & 0.720 \\
\hline Emotional Experience & 0.582 \\
\hline Reputation & 0.674 \\
\hline
\end{tabular}

Source: SmartPLS 03 calculation results, $\mathrm{n}=100$

(2020)

The value of AVE (Average Variance Extracted) and the value of communality in table 2 show the results that the value is greater than 0.5 . It can be concluded that all variables in this study meet the convergent validity test requirements. This means that more than half the indicators forming variables can be explained by the parent variable. 
Effect of Emotional Experience, Electronic Word of Mouth, Reputation, Customer Satisfaction on Loyalty (Empirical Study: Lion Air)

Wijaya \& Yulita

Reliability test can be done by looking at the value of Cronbach's alpha and composite reliability

Table 3.

Cronbach's Alpha dan Composite Reliability

\begin{tabular}{l|c|c}
\hline & Cronbach's Alpha & Composite Reliability \\
\hline E-Wom & 0.841 & 0.894 \\
\hline Consumer Satisfaction & 0.850 & 0.898 \\
\hline Loyalty & 0.806 & 0.885 \\
\hline Emotional Experience & 0.819 & 0.874 \\
\hline Reputation & 0.838 & 0.892 \\
\hline
\end{tabular}

Source: SmartPLS 03 calculation results, $\mathrm{n}=100$

(2020)

Cronbach's alpha value and composite reliability of all variables showed values greater than 0.7, which means that all variables in this study were considered to meet the reliability test.

Determination test can be done by looking at the value of $\mathrm{R}$-square $\left(\mathrm{R}^{2}\right)$. In table 4 shows the value of $\mathrm{R}$-square $\left(\mathrm{R}^{2}\right)$ in this study.

Table 4.

R-Square $\left(\mathrm{R}^{2}\right)$

\begin{tabular}{lc}
\hline & R-Square \\
\hline E-Wom & 0.74 \\
\hline Consumer Satisfaction & 0.60 \\
\hline Loyalty & 0.76 \\
\hline Reputation & 0.79 \\
\hline
\end{tabular}

Source: SmartPLS 03 calculation results, $\mathrm{n}=100$

(2020)

Based on the R-square value $\left(\mathrm{R}^{2}\right)$ in table 4 it can be concluded that the EWOM variable is influenced by the variable of emotional experience and customer satisfaction by 0.747 or $74.7 \%$ and the rest can be explained or influenced by other variables. The variable of customer satisfaction is influenced by emotional experience variables of 0.604 or $60.4 \%$ and the rest can be explained or influenced by other variables.

The loyalty variable is influenced by the EWOM variable, customer satisfaction and reputation by 0.766 or $76.6 \%$ and the rest can be explained or influenced by other variables. While the reputation variable is influenced by the emotional experience variable, EWOM, customer satisfaction by 0.792 or $79.2 \%$ and the rest can be explained or influenced by other variables.

The relationship of variables is said to be significant if the t-statistic is greater than the t-table which is 1.96 .

Table 5.

t-statistik value

\begin{tabular}{l|c|c|c}
\hline & Hipotesis & T-Statistik & Notes \\
\hline Emotional Experience $\rightarrow$ Consumer Satisfaction & H1 & 21.209 & Accepted \\
\hline Emotional Experience $\rightarrow$ EWOM & H2 & 5.941 & Accepted \\
\hline Emotional Experience $\rightarrow$ Reputation & H3 & 0.366 & Rejected \\
\hline Consumer Satisfaction $\rightarrow$ Loyalty & H4 & 0.051 & Rejected \\
\hline Consumer Satisfaction $\rightarrow$ EWOM & H5 & 5.129 & Accepted \\
\hline
\end{tabular}


Effect of Emotional Experience, Electronic Word of Mouth, Reputation, Customer Satisfaction on Loyalty (Empirical Study: Lion Air)

Wijaya \& Yulita

\begin{tabular}{l|c|c|c}
\hline & Hipotesis & T-Statistik & Notes \\
\hline Consumer Satisfaction $\rightarrow$ Reputation & H6 & 2.164 & Accepted \\
\hline Reputation $\rightarrow$ Loyalty & H7 & 5.341 & Accepted \\
\hline E-Wom $\rightarrow$ Reputation & H8 & 6.277 & Accepted \\
\hline E-Wom $\rightarrow$ Loyalty & H9 & 3.141 & Accepted \\
\hline
\end{tabular}

Source: SmartPLS 03 calculation results, $\mathrm{n}=100$ (2020)

Positive emotional experience has positive effect on Lion Air airline customer satisfaction. Then $\mathrm{Ha1}$ is accepted and $\mathrm{Ho1}$ is rejected, with a t-statistic value of 21,209>1.96.

In this study, positive emotional experience has a positive effect on customer satisfaction of Lion Air airlines. This is based on the t-statistic value in table 5 which shows that the influence of emotional experience variables on customer satisfaction by 21,209 is greater than the t-table value of 1.96 which means that Ha1 is accepted and Ho1 is rejected. The results of this study are in accordance with research (Serra-Cantallops, Ramon-Cardona, \& Salvi, 2018) which states that emotional experiences influence customer satisfaction at a hotel in Germany.

Based on the results of this study it can be concluded that the positive emotional experience has a positive effect on consumer satisfaction of the Lion Air airline. Respondents who contributed in this study felt that the emotional experience gained from the services provided by the Lion Air airline was better than consumer expectations, certainly increasing consumer satisfaction with the Lion Air airline.

Positive emotional experience has a positive effect on electronic word of mouth on the airline Lion Air. Then $\mathrm{Ha} 2$ is accepted and $\mathrm{Ho} 2$ is rejected, with a t-statistic value of 5.941> 1.96 .

In this study, positive emotional experience has a positive effect on electronic word of mouth on the airline Lion Air. This is based on the t-statistic value in table 5 which shows that the influence of the emotional experience variable on electronic word of mouth is 5,941 greater than the t-table value of 1.96 which means that $\mathrm{Ha} 2$ is accepted and Ho2 is rejected. The results of this study are consistent with research (Serra-Cantallops, Ramon-Cardona, \& Salvi, 2018) which states that emotional experiences affect the electronic word of mouth in a hotel in Germany.

Based on the results of this study it can be concluded that a positive emotional experience has a positive effect on electronic word of mouth on the airline Lion Air. Respondents who contributed in this study felt that due to good emotional experiences, consumers felt they wanted to share their experiences with other potential customers, where consumers now prefer to share their experiences through electronic social media.

Positive emotional experience does not have a positive effect on the reputation of the Lion Air airline. Then $\mathrm{Ho} 3$ is accepted and $\mathrm{Ha} 3$ is rejected, with a t-statistic value of 0.366 $<1.96$.

In this study, positive emotional experience did not have a positive effect on the reputation of the Lion Air airline. This is based on the t-statistic value in table 5 which shows that the influence of the emotional experience variable on reputation is 0.366 smaller than the t-table value of 1.96 which means that $\mathrm{Ho} 3$ is accepted and $\mathrm{Ha} 3$ is rejected. The results of this study differ from studies (Serra-Cantallops, Ramon-Cardona, \& Salvi, 2018) which state that emotional experiences affect the reputation of a hotel in Germany.

Based on the results of this study it can be concluded that positive emotional experiences do not have a positive effect on the reputation of the Lion Air airline. Respondents who 
Effect of Emotional Experience, Electronic Word of Mouth, Reputation, Customer Satisfaction on Loyalty (Empirical Study: Lion Air)

Wijaya \& Yulita

contributed in this study felt that the experience experienced by each customer would certainly be different - the reputation built by the airline Lion Air is an airline with a lower flight ticket price than other airlines, so that the emotional experience of consumers will not affect other consumers who want use the Lion Air airline because of the cheap ticket prices.

Consumer satisfaction does not have a positive effect on Lion Air airline customer loyalty. Then $\mathrm{Ho} 4$ is accepted and $\mathrm{Ha} 4$ is rejected with a t-statistic value of $0.051<1.96$.

In this study, customer satisfaction has a positive effect on electronic word of mouth on the airline Lion Air. This is based on the t-statistic value in table 5 which shows that the effect of consumer satisfaction variables on electronic word of mouth is 5.129 greater than the t-table value of 1.96 which means that $\mathrm{Ha} 5$ is accepted and Ho5 is rejected. The results of this study differ from studies (Serra-Cantallops, Ramon-Cardona, \& Salvi, 2018) which state that consumer satisfaction affects the electronic word of mouth in a hotel in Germany.

Based on the results of this study it can be concluded that customer satisfaction has a positive effect on electronic word of mouth on the Lion Air airline. Respondents who contributed in this study felt that the crash of a Lion airplane made Lion Air's electronic word of mouth worse. This is a dissatisfaction of consumers who are disappointed because the incident occurred due to aircraft engines that are not good enough to make the aircraft lose control and fall. Therefore, in this study, consumer disappointment affects electronic word of mouth.

Consumer satisfaction has a positive effect on electronic word of mouth on the airline Lion Air. Then $\mathrm{Ha} 5$ is accepted and $\mathrm{Ho5}$ is rejected with a t-statistic value of 5.129>1.96.

In this study, customer satisfaction has a positive effect on electronic word of mouth on the airline Lion Air. This is based on the t-statistic value in table 5 which shows that the effect of consumer satisfaction variables on electronic word of mouth is 5.129 greater than the t-table value of 1.96 which means that $\mathrm{Ha} 5$ is accepted and Ho5 is rejected. The results of this study differ from studies (Serra-Cantallops, Ramon-Cardona, \& Salvi, 2018) which state that consumer satisfaction affects the electronic word of mouth in a hotel in Germany.

Based on the results of this study it can be concluded that customer satisfaction has a positive effect on electronic word of mouth on the Lion Air airline. Respondents who contributed in this study felt that the crash of a Lion air plane made Lion Air's electronic word of mouth worse. This is a dissatisfaction of consumers who are disappointed because the incident occurred due to aircraft engines that are not good enough to make the aircraft lose control and fall. Therefore, in this study, consumer disappointment affects electronic word of mouth.

Consumer satisfaction has a positive effect on the reputation of the Lion Air airline. Then $\mathrm{Ha6}$ is accepted and $\mathrm{Ho6}$ is rejected with a t-statistic value 2.164> 1.96.

In this study, customer satisfaction has a positive effect on the reputation of the Lion Air airline. This is based on the t-statistic value in table 5 which shows that the influence of customer satisfaction variables on reputation is 2,164 greater than the t-table value of 1.96 which means that Ha6 is accepted and Ho6 is rejected. The results of this study are consistent with research (Walsh, Jackson, Mitchell, \& Beatty, 2009) stating that consumer satisfaction affects the reputation of an energy supplement company in Germany.

Based on the results of this study it can be concluded that customer satisfaction has a positive effect on the reputation of the Lion Air airline. Respondents who contributed in this study felt that satisfied consumers would influence the reputation of the Lion Air airline. 
Effect of Emotional Experience, Electronic Word of Mouth, Reputation, Customer Satisfaction on Loyalty (Empirical Study: Lion Air)

Wijaya \& Yulita

Consumers will link a good reputation with the company if they meet or exceed their expectations when using products or services.

\section{Reputation has a positive effect on Lion Air airline customer loyalty. Then Ha7 is accepted and $\mathrm{Ho} 7$ is rejected with a t-statistic value of 5.341> 1.96.}

In this study, reputation has a positive effect on Lion Air airline customer loyalty. This is based on the t-statistic value in table 5 which shows that the influence of the reputation variable on loyalty is 5,341 greater than the t-table value of 1.96 which means that $\mathrm{Ha} 7$ is accepted and Ho 7 is rejected. The results of this study are consistent with research (Ali, Alvi, \& Ali, 2012) stating that reputation influences loyalty in a cellular telephone industry in Pakistan.

Based on the results of this study it can be concluded that reputation has a positive effect on consumer loyalty of the Lion Air airline. Respondents who contributed in this study felt that when a company's reputation is good, consumers will be loyal to the company, because reputation will create repeat buying behavior from consumers. Companies that can build a strong reputation will leave an imprint on the memories of consumers who have already bought and potential consumers.

Electronic word of mouth has a positive effect on the reputation of Lion Air. Then Ha8 is accepted and $\mathrm{Ho8}$ is rejected with a t-statistic value of 6.277> 1.96.

In this study, electronic word of mouth has a positive effect on the reputation of the Lion Air airline. This is based on the t-statistic value in table 4.6 which shows that the effect of electronic word of mouth variable on reputation is 6,277 greater than t-table value of 1.96, which means $\mathrm{Ha} 8$ is accepted and Ho8 is rejected. The results of this study are in accordance with research (Serra-Cantallops, Ramon-Cardona, \& Salvi, 2018) showing that electronic word of mouth is related to consumer reviews, from the review there is a rating related to the reputation of a hotel in Germany.

Based on the results of this study it can be concluded that electronic word of mouth has a positive effect on the reputation of the Lion Air airline. Respondents who contributed in this study felt that electronic word of mouth related to the reviews of consumers who have made purchases or use services, from the reviews formed a rating of a company that is related to reputation. Therefore, when a company has a bad electronic word of mouth, its reputation will be bad, and vice versa.

Electronic word of mouth has a positive effect on the loyalty of the Lion Air airline. Then $\mathrm{Ha} 9$ is accepted and $\mathrm{Ho}$ is rejected with a t-statistic value 3.141> 1.96.

In this study, electronic word of mouth has a positive effect on the loyalty of the Lion Air airline. This is based on the t-statistic value in table 4.6 which shows that the influence of electronic word of mouth variables on loyalty is 3,141 greater than the t-table value of 1.96 which means that $\mathrm{Ha} 9$ is accepted and $\mathrm{Ho} 9$ is rejected. The results of this study differ from studies (Setiawan, Troena, Armanu, \& Noermijati, 2014) which state that electronic word of mouth has no positive effect on loyalty in a destination in Denpasar, Bali. But this study is in accordance with research (Serra- Cantallops, Ramon-Cardona, \& Salvi, 2018) which states that electronic word of mouth has a positive effect on loyalty in a hotel in Germany.

Based on the results of this study it can be concluded that electronic word of mouth has a positive effect on the loyalty of the Lion Air airline. Respondents who contributed in this study felt that after the crash of one of the Lion Air planes, they did not make loyal customers because of the cheap ticket prices, no longer using Lion Air, electronic word of mouth obtained by 
Effect of Emotional Experience, Electronic Word of Mouth, Reputation, Customer Satisfaction on Loyalty (Empirical Study: Lion Air)

Wijaya \& Yulita

consumers that could come from social media, news and other electronic media do not make consumers not use the airline Lion Air again.

\section{CONCLUSION}

Positive emotional experience has a positive effect on consumer satisfaction of Lion Air airline, meaning that respondents involved in this study feel the emotional experience gained when using Lion Air airline affects customer satisfaction.

Positive emotional experience has a positive effect on electronic word of mouth on the Lion Air airline, meaning that respondents involved in this study make information to other potential customers about their experiences when using the Lion Air airline.

Positive emotional experience does not have a positive effect on the reputation of the Lion Air airline, meaning that the respondents involved in this study the emotional experience of consumers do not make down the reputation of Lion Air which has a reputation for low prices compared to other airlines.

Consumer satisfaction does not have a positive effect on Lion Air airline customer loyalty, meaning that respondents involved in this study consumers who in terms of satisfaction obtained from services do not necessarily form loyalty to Lion Air consumers.

Consumer satisfaction has a positive effect on electronic word of mouth on the Lion Air airline, which means that respondents involved in this study feel satisfied consumers will make a review of the Lion Air airline.

Consumer satisfaction has a positive effect on the reputation of the Lion Air airline, meaning that respondents involved in this study feel satisfied consumers will certainly bring a good reputation for the company, which in this case is the Lion Air airline.

Reputation has a positive effect on Lion Air airline customer loyalty, meaning that the respondents involved in this research have a good reputation and will also bring a good image that can build consumer loyalty to reuse a product or service.

Electronic word of mouth has a positive effect on the reputation of the airline Lion Air, meaning that respondents involved in this study good reviews will also have a positive impact on the reputation of the airline Lion Air, as well as that where when a bad review then the reputation will also decline.

Electronic word of mouth has a positive effect on the loyalty of the Lion Air airline, meaning that respondents involved in this study good reviews will make consumers put our products or services when they want to reuse, so that good reviews will form loyalty in terms of repeat purchases.

Based on the conclusions explained above, the researcher gives several suggestions in the form of:

1. For Marketers and Companies.

First, for companies to be better in terms of monitoring electronic word of mouth, namely reviews made by consumers, companies can create a complaint and information forum so that they can directly accommodate and process unfavorable reviews, so that it does not affect the opinions of potential customers others who want to use the Lion Air airline.

Second, companies can build a reputation by improving their service to consumers, so far Lion Air is remembered by the reputation of airlines with the longest delays, and damaging consumer goods. The right choice for a Lion Air airline that makes a policy is only cabin baggage due to speeding up crew time to prepare for the next flight. 
Effect of Emotional Experience, Electronic Word of Mouth, Reputation, Customer Satisfaction on Loyalty (Empirical Study: Lion Air)

Wijaya \& Yulita

Third, in terms of loyalty, Lion Air is known as the airline with a lower price range compared to other airlines. Therefore, it is good for the Lion Air airline to keep the ticket price, and not make an increase. This can be helped by baggage restrictions too, so as not to make a loss on the Lion Air airline.

2. For Further Researchers

The researcher hopes that with this research, the next researcher can develop the deficiencies of this research model. The researcher also hopes that the next researcher can be more specific in explaining both the theory, the research method, and the dimensions of each variable.

\section{REFERRENCES}

Afiyanti, Y. (2008). Validitas dan Reliabilitas dalam Penelitian Kualitatif. Jurnal Keperawatan Indonesia, 12(2), 137-140.

Bara, G. (2020, Juni 15). Diambil kembali dari https://rumusrumus.com/objekpenelitian/\#Pengertian_Objek Penelitian

databoks.katadata.co.id. (2018, Desember 12). Diambil kembali dari https://databoks.katadata.co.id/datapublish/2018/12/20/penumpang-pesawatpenerbangan-domestik-januari-oktober-2018-tumbuh-7

Hartomo, G. (2018, December 13). Sektor Riil. Retrieved March 19, 2019, from economy.okezone.com:

https://economy.okezone.com/read/2018/12/13/320/1990797/menhub-beberkankinerja-transportasi-dalam-4-tahun-ini-hasilnya

Isdianto, O., \& Kurniawan, I. S. (2017). Pengaruh Praktek Msdm Strategik Dan Kinerja Karyawan Terhadap Kinerja Perusahaan Persewaan Alat Pesta Or (Studi Kasus Pada Perusahaan Persewaan Alat Pesta Oki Rejeki). Jurnal Manajemen Dewantara, 1(2), 56-60.

Lestari, A. (2018). PENGARUH KUALITAS PRODUK TERHADAP LOYALITAS PELANGGAN DENGAN KEPUASAN PELANGGAN SEBAGAI VARIABEL MEDIASI. Jurnal Administrasi Bisnis (JAB)|Vol. 54 No. 1 Januari, 74-81. makassar.tribunnews.com. (2019, Februari 13). Diambil kembali dari https://makassar.tribunnews.com/2019/02/13/deretan-insiden-kecelakaan-pesawatlion-air-dari-jatuh-tergelincir-delay-hingga-bagasi-berbayar

Matondang, Z. (2009). Validitas Dan Reliabilitas Suatu Instrumen Penelitian. Jurnal Tabularasa Pps Unimed, 6(1), 87-96.

Mirza, A. F. (2016). Hubungan antara Emotional Branding dengan Loyalitas Merek pada Konsumen Kartu Seluler XL. Jurnal Psikologi Integratif, 4(1), 63-72.

Noviyanti, D., Yuniarti, D., \& Amijaya, F. D. (2016). Pemodelan Regresi Variabel Mediasi Dengan Metode Product Of Coefficient. Prosiding Seminar Sains dan Teknologi FMIPA Unmul, 1(1), 37-40.

Serra-Cantallops, A., Ramon-Cardona, J., \& Salvi, F. (2018). The impact of positive emotional experience on eWOM generation and loyalty. Spanish Journal of Marketing - ESIC, 22(1), 142-162.

Setiawan, P. Y., Troena, E. A., Armanu, \& Noermijati. (2014). The Effect of e-WOM on Destination Image, Satisfaction and Loyalty. International Journal of Business and Management Invention, 3(1), 22-29. 
Effect of Emotional Experience, Electronic Word of Mouth, Reputation, Customer Satisfaction on Loyalty (Empirical Study: Lion Air)

Wijaya \& Yulita

Solimun, Armanu, \& Fernandes, A. A. (2018). Metodologi Penelitian Kuantitatif Perspektif Sistem. Malang: UB Press.

Suhasto, I. N. (2018). Pengaruh Kualitas Pelayanan dan Kedekatan Emosional Terhadap Loyalitas Nasabah. Jurnal Inspirasi Bisnis dan Manajemen, Vol 2, (1), 55-64.

Sukmana, Y. (2018, November 26). Bisnis. Retrieved April 22, 2019, from Kompas.com: https://ekonomi.kompas.com/read/2018/11/26/184417226/mengupas-citra-gemardelay-dan-tak-aman-maskapai-bertarif-murah

Walsh, G., Jackson, P. R., Mitchell, V.-W., \& Beatty, S. E. (2009). Examining the Antecedents and Consequences of Corporate Reputation: A Customer Perspective. British Journal of Management, 20(2), 187-203.

Widanaputra, A. A. (2018). REPUTASI PERUSAHAAN, REPUTASI MANAJEMEN PUNCAK, DAN PENGUNGKAPAN CORPORATE SOCIAL RESPONSIBILITY. Jurnal Ilmiah Akuntansi dan Bisnis, Vol. 76 13, No. 2, Juli, 75-84. 